\title{
Impact of Financial Institution on Commercial Banks (Case Study: Amal and Dahabshiil Banks in Mogadishu)
}

\author{
Mr. Abdifatah Dahir Harun* \\ Horseed International University - Hiu \\ *Corresponding Author: Mr. Abdifatah Dahir Harun, Horseed International University - Hiu

\begin{abstract}
This research examines how remittance service satisfy the commercial banks and financial institutions and their function, I also focus on what caused the growth of remittance services and increasing and how they filled their service how they effected the society and I society focus on Dahabshiil and Amal that massively effected to these services and how their new banks effected the need of commercial banks and financial institutions
\end{abstract}

This study consisted of secondary data qualitative data and structured service of survey and questionnaire method.

This study investigated four specific questions

- How Dahabshiil and Amal satisfied the need of commercial banks and financial instructions

- Do you satisfy the performance of remittance companies for the lack of banks?

- Is there a relationship between the financial institution and commercial banks?

The study found that there seems to be significant relationship between financial institutions and commercial banks in Somalia. The study recommends that remittance companies must develop system which connects $s$ the one who served and one who has profitable business but an idea is to have fund and investment to business.

\section{INTRODUCTION}

\subsection{Background of the Study}

The Bank of England has had much success and as a result many nations have followed its lead in creating central bank systems of their own. The United States is one of these nations. The two nations have many similar banking objective and strategies on how to best achieve the objectives. These nations also differ greatly in some aspects of their banking philosophies. The currencies of the both nations are strong held around the world. Their monetary policies and bank regulations differ in some aspects, but both nations banking systems are held to high esteem worldwide. The banking systems of the United States and the United Kingdom were born of the same origins but differ in some major aspects of practice (Pierre 2001).

The United States monetary system was greatly influenced by that of the United Kingdom. The United States Federal Reserve Board and United Kingdom's monetary policy committee are both used to regulate the economy and are similar to one another. The Federal Reserve System is the central bank of the United States and was established by congress in 1913. The bank of England is the central bank of the United Kingdom and plays the same role as the Federal Reserve. The main roles of the federal reserve is to influenced the money and credit conditions to achieve stable prices, supervises and regulate banking institutions, maintain the stability of the financial system, and provide financial services to the US government, the public. Financial institutions, and foreign official institutions (federal reserve board homepage). Before the Bank of England Act of 1998, the United Kingdom and United States were similar in that their central banking institutions were in charge of these same four objectives. Now the difference is that the Federal Reserve supervises open market operations, where the United Kingdom the treasury supervises open market operations (Siklos 2001). 
The Bank of England and the Federal Reserve's main objective for monetary policy is price stability, while maintaining economic health. To maintain economic health they focus on maintaining low levels of unemployment and a high GDP.

\section{LITERATURE REVIEW}

\subsection{Concept of Financial Institutions}

Deposit-taking institutions that accept manage deposit and make loans companies banking, banking institution serving general public an institution that is licensed to receive money on deposit from private individuals and to pay interest on it, for example, a bank or savings and loan deposit-taking institution. (Shamus Rae).

Three major types of financial institutions:

- Deposit-taking institutions that accept and manage deposits and make loans, including banks, building societies, credit unions, trust companies and mortgage loan companies.

- Insurance companies and pension funds; and

- Brokers, underwriters and investment funds.

Commercial banks and financial institutions including:-

- Processing of payments by ways of transferee, internet banking and other means.

- Accepting money on terms of deposit.

- Lending money to trusted individuals and business companies or other means.

The importance of financial institutions especially, bank in generating growth within the economy has been widely discussed in literature. Several economists have argued that the role of intermediation which banks play help in providing linkages for different sectors of the economy as well as encouraging high level of specialization, expertise, economies of scale and creating a conducive environment for the implementation of various economic policies of government. For instance, Schumpeter (1912) as cited in Zakaria (2008), argued that financial intermediation through the banking system plays an essential role in economic development by affecting the allocation of savings, thereby improving productivity, technical change and the rate of economic growth. $\mathrm{He}$ acknowledged that efficient savings through identification and funding entrepreneurs is vital to achieving desired objectives. Thus, one of the activities of financial institutions involves intermediating between the surplus and deficit sectors of the economy.

\subsection{Financial Intermediation}

Finance is required for different purposes by different organizations, individuals and other economic agents. In order to provide the needed finance, there are varieties of institutions rendering financial services. Such institutions are called financial institutions. Commercial banks are among such institutions that render financial services. They are mainly involved in financial intermediation, which involves channeling funds from the surplus unit to the deficit unit of the economy, thus transforming bank deposits into loans or credits.

In the primitive stages before evolution for financial intermediation, anyone who needs to spend more than he could himself provide would have to look for a wealthy person or persons from whom he could borrow. This is known as a system of direct or un-intermediated finance. Afolabi (1998) posits that as crude as this system was, it probably satisfied the need of that time because financial requirements then were limited to such personal uses like marriages, burial ceremonies and minor commercial activities like farming.

He further argued that at that time, intermediation was neither necessary nor sufficient for capital formation to take place.

Financial intermediation will thus, not be necessary for instance, if the lender and the borrower can come into direct contact and would in fact not be necessary if there is no deficit or surplus sector. However, modern economic transactions will be difficult, if not impossible, with un-intermediated finance as the business world nowadays is much more complex and financial requirements are too large. Even without considering the complexity of modern times, un-intermediated finance has its 
inherent problems such as high tendency for subjectivity, unattractive interest rates, method of security was too crude and at times inhuman, repayment periods were usually too short for any meaningful long-term use, such that it became difficult for long-term projects to be financed from money raised from such medium amongst others. According to Bencivenga and Smith (1991), in the absence of banks i.e. financial intermediation, too much investment is self-financed and long delays exist between investment expenditure and receipts of profits from capital invested. They further argued that the absence of intermediary sector results in a composition of savings that is unfavorable to capital formation. Thus, an intermediation industry permits an economy to reduce the fraction of the savings held in the form of unproductive liquid assets, and to prevent misallocations of invested capital due to liquidity needs.

The argument just given suggests that financial intermediaries may naturally tend to alter the composition of savings in a way that is favorable to capital accumulation. Then, if the composition of savings affects real growth rates, intermediacies will tend to promote growth. Here, the analysis draws heavily on the contributions of the "endogenous growth" literature, as exemplified by Romer (1986) and Lucas (1988). One of the many insights of this literature is that savings behavior will generally influence equilibrium growth rates. In particular, to the extent that intermediaries tend to promote capital investment, they will also tend to raise rates of growth.

A requirement of Financial Intermediation Afolabi (1998) posits that for financial intermediation to succeed, three qualities are essential. These are usually called the three C's of intermediation namely: cost, convenience and confidence.

NWAEZE CHINWEOKE*, MICHAEL ONYDIKACHI** AND NWABEKEE CHIDINMA ELIZABETH*, The Macrotheme Review 3(6), Summer 2014130 Cost Costs refer to the transaction cost that the saver or borrower is made to bear in the process of his dealing with the intermediary. Thus, costs like bank charges, commission and interest payable must be considerably low. For instance, the local money lenders most times charge very exorbitant interest, hence only hard pressed people, who are not likely to be credit-worthy to the bank, do patronize them. If there is appreciable cost of transacting business with an intermediary, many people will prefer to by-pass them.

\section{MeThOdology}

\subsection{Research Design}

This study the researcher will employ quantitative correlation research design is using for investigation of this study. According this study the researches make investigation about commercial bank and financial institutions: evidence from banking service sector in Mogadishu Somalia and also conduct quantitative design; quantitative design is any data that is in numerical from such as statistics, percentage, etc. in layman's terms, this means that the quantitative researcher asks a specific, narrow question and collects numerical data from participants to answer the questions as cited in (Leahey et al, 2008).

\subsection{Research Population}

The research population generally will be banking sector in which researcher select Dahabshiil and Amal banks. Because they are popular in society more than others particular the customer of those two banks. Therefore the exact number of the population is unknown.

This study researcher selects 60 customers of these two banks of Amal and Dahabshiil banks.

\subsection{Sample size}

In view of the nature the target population where the number is too small to take a sample, we need almost the entire population in order to achieve accuracy as the sample size is equal to the population size, the variance is equal to zero in this case there is no uncertainty about population proportion (Morris, n.t.d).

\subsection{Sample Procedure}

The researchers considering the complexity of the research topic, all the customer did not make the desired target population in the regard of their knowledge to the research topic and holding the necessary information on the topic of research. So that, the researchers decide non probability 
sampling by using purpose or judgment sampling, had selected the customer of these two banks due to their knowledge and information for the topic of research.

\subsection{Research Instruments}

\section{Questionnaires}

The research will use different methods of data collection the tool that we use our research is questionnaires will use to extract information from employees in various departments of financial institution and commercial banks of select Dahabshiil and Amal banks. Questionnaires were use because of the advantage of extracting a lot of information from many employees in a short period of time.

\subsection{Reliability and Validity of the Instrument}

The reliability of the research instruments concerned with the degree to which the research instrument give way the same result. Reliability of the respondent's instruments questionnaire was establish through a test-retested method. The researcher conducted a pre-test for the instruments questionnaire in Mogadishu and the test was conduct after one week in the same city and the same respondents and it gave the researcher the same result. This allows the constancy and the reliability of the instruments. Validity is the quality of the test doing what is designed to do (Salkind, 2000).

\subsection{Data Analysis}

The data analysis for this study was conduct through correlation analysis, 'Statistical Package for Social Science' software or SPSS version 17. Correlation Statistics fit into this study because the researcher search for answers the questions asked to the staff of the bank, and even questionnaire is one of classical techniques to collect correlation data (Principe, 2005). Data collect from the field, presented through descriptions and analysis as adapt. The responses of each item of close-ended type were analyzed in terms of number of describe responses. The frequencies further were converted into correlation to describe the result of the item to arrive at the findings.

\section{Analysis of Data}

\subsection{Introduction}

The data gathered from the Amal bank and Dahabshiil bank interviewed in the Mogadishu are presented and analyzed. This chapter explanations the results of the questionnaire and interview responded by $60 \%$ respondents in the said agree of the study.

Deposit-taking institutions accept, manage deposit and make loans companies the most respondents select agree while some people has showing the doubt the new emerging banks in Mogadishu. The customer hope to get commercial bank financial institutions that covers their needs. This question the most respondent show people hope their needs to satisfy.

Firstly to the analysis of the questionnaire process, the purpose, the important and objectives of the study were relayed to the respondents. They were also real that all the information they had provided are only for the purpose of the study while their identities would remain confidential. Every question asked in the interview and controlled questionnaire relate only to the respondents' insights on the impact of commercial bank and financial institutions data presentation, the findings of the questionnaire are presented in graphs and tables. To give aright flow of discussion, findings are also divided into parts. Part one gives aoutline of the demographic profile of the respondents used in the study. This profile was categorized according to the respondents' gender and educational level status. The discussion within Dahabshiil and Amal bank as described by the respondents is presented on the second pat. On the third part, focus is on the respondents' response to the status of the services offered by Amal and Dahabshiil bank. Lastly, part four will present the in general analysis of the data gathered in the semi-structured interview pertaining to the managers' concrete experiences, satisfaction level as well as their suggestion on how current change management procedures within Amal bank and Dahabshiil bank may be improved.

\subsection{Part 1: Demographic Profile}

A total of 60 respondents were used for the data gathering process of the study. The participants were employees working at Dahabshiil bank and Amal bank. For the purpose of gathering important and 
reliable data respondents of the $51.7 \%$ and $49.3 \%$ respondents these categories include the respondents' male, female status.

\begin{tabular}{|l|c|}
\hline Gender & \\
\hline Male & 31 \\
\hline Female & 29 \\
\hline
\end{tabular}

Descriptive summary of the 60

\subsection{Respondents of the Study}

As seen on the table, the respondents were equally divided according to the two categories as selected by the researcher. This is for the objectives of giving a sameillustration of the respondents regarding the subject matter. Since the research could not give for a much bigger sample due to time and budgetary constraints, the equal symbol of respondents can represent the significant sample categories.

\subsection{Part 2: Cash Management}

As most of the respondents of the study were Dahabshiil and Amal bank, the way they perceived the manner in which the management handled the changes that happened after commercial bank and financial institutions appeared to be varied as well. In Figure 1, although a greater number of respondents said that the management changes that happened after treasury management was handled properly by the company; the results of the participants' responses seemed to be slightly welldistributed among the survey choices given.

\section{DISCUSSIONS AND INTERPRETATIONS OF FINDINGS}

\subsection{Introduction}

This chapter discusses the results in light of the study's research questions, literature review, and conceptual framework. Finding patterns and themes is one result of analysis. Finding ambiguities and inconsistencies is another. Overall, this chapter offers the researcher an opportunity to reflect thoroughly on the study's findings, and the practical and theoretical implications thereof

\subsection{Discussion}

This part provides an in-depth interpretation, analysis, and the results/findings.

- Analysis is seeking emergent patterns among findings can be considered a first round of analysis. Examining whether the literature corresponds with, contradicts, and/or deepens

This chapter reflects a deep understanding of what lies beneath the findings - that is, what those findings really meaning. Interpretation is presented systematically, and is related to the literature, conceptual framework, and interpretive themes or patterns that have emerged. A key characteristic of qualitative research is willingness to tolerate ambiguity. As such, examining issues from all angles in order to demonstrate the most plausible explanations is an indication of high-level analysis. Integrity as a researcher is given credence by inclusion of all information, even that which challenges inferences and assumptions

\subsection{The Objectives of Respondent's Question and Descriptive Statistics}

This provides the response rate of all questionnaires issues and justification of why that response rate is adequate for data analysis. It is important to message that a response rate of at least $60 \%$ agrees and recommended to accept deposit and taking real commercial bank. Further this section provides the descriptive analysis of the background information using the descriptive statistics; this part is overall the longest parts of the research development. The objective is to descript and explain the data rather than draw interpretations or conclusions. The answer should be presented and calculated on the basis of the research questions, specific, purpose or hypotheses.

Would describe tables and figures should be used to analysis quantitative data when appropriate. A brief description in words of what is shown in the table or figure should be provided. A general rule is to prepare the table or figure and the text, in such a way that they can stand alone in describing the outcomes of the study. 
Impact of Financial Institution on Commercial Banks (Case Study: Amal and Dahabshiil Banks in Mogadishu)

\subsection{Analysis of Responses and Objectives}

The objective one the mostly respondent were highly agree, disagree medium while strongly agree can influences all of them.

Second objective would present the assessment of cash management and treasury services of the commercial banks and financial institutions that were part of development.

The need is you feeling for lack of the commercial banks and financial institutions. This answer was explain the table 12 the responds of the people and their idea to express the lack commercial bank and financial role were $13.3 \%$ agree while $61.7 \%$ disagree this analysis show how to influence disagree this question. Also table14 express the changes that banks can bring $43.3 \%$ suggest agree $10 \%$ disagree, $35 \%$ strongly agree while $11.7 \%$ strong disagree.

\begin{tabular}{|c|c|c|c|c|c|c|c|c|}
\hline \multicolumn{9}{|c|}{ Descriptive Statistics } \\
\hline & $\mathbf{N}$ & Range & Minimum & Maximum & Sum & Mean & \begin{tabular}{|c|} 
Std. \\
Deviation
\end{tabular} & Variance \\
\hline $\begin{array}{l}\text { 1. local companies such Dahabshiil and } 6 \\
\text { Amal provide you some functions of } \\
\text { financial institution and commercial } \\
\text { banks }\end{array}$ & & 3 & 1 & 4 & 96 & 1.60 & .906 & .820 \\
\hline $\begin{array}{l}\text { 2. Amal and Dahabshiil provide the } 6 \\
\text { process of payment the ways of } \\
\text { transferring internet banking }\end{array}$ & & 3 & 1 & 4 & 126 & 2.10 & .933 & .871 \\
\hline $\begin{array}{l}\text { 2. The people satisfy the performance } 6 \\
\text { of the remittance companies for the } \\
\text { lack of banks }\end{array}$ & & 3 & 1 & 4 & 120 & 2.00 & .957 & .915 \\
\hline $\begin{array}{l}\text { 3. Amal and Dahabshiil accept money } 6 \\
\text { on terms on deposit }\end{array}$ & 60 & 3 & 1 & 4 & 126 & 2.10 & .986 & .973 \\
\hline $\begin{array}{l}\text { 4. Some people believe that remittances } 6 \\
\text { companies can cover some of needs } \\
\text { of the banks }\end{array}$ & & 3 & 1 & 4 & 129 & 2.15 & .917 & .842 \\
\hline $\begin{array}{l}\text { 5. People has doubt the new emerging } 6 \\
\text { banks of Amal Dahabshiil }\end{array}$ & 50 & 3 & 1 & 4 & 126 & 2.10 & .969 & .939 \\
\hline $\begin{array}{l}\text { 6. Amal and Dahabshiil had covered } 6 \\
\text { the needs of the banks in your need }\end{array}$ & & 3 & 1 & 4 & 125 & 2.08 & 1.094 & 1.196 \\
\hline $\begin{array}{l}\text { 7. Customer hope to get commercial } 6 \\
\text { bank and financial institutions that } \\
\text { covers your need }\end{array}$ & & 3 & 1 & 4 & 130 & 2.17 & 1.107 & 1.226 \\
\hline $\begin{array}{l}\text { 8. The need is you feeling for the lack } 6 \\
\text { of the commercial banks and } \\
\text { financial institutions }\end{array}$ & & 3 & 1 & 4 & 135 & 2.25 & .856 & .733 \\
\hline $\begin{array}{l}\text { 9. Your family depends on the } 6 \\
\text { remittances for the lack of the } \\
\text { commercial and financial institutions }\end{array}$ & & 3 & 1 & 4 & 123 & 2.05 & 1.096 & 1.201 \\
\hline $\begin{array}{l}\text { 10. Mogadishu societies feel the absence } 6 \\
\text { strong government intervention and } \\
\text { emerging new free commercial banks }\end{array}$ & & 3 & 1 & 4 & 129 & 2.15 & 1.117 & 1.248 \\
\hline $\begin{array}{l}\text { 11. The main risk that you a fraying to } 6 \\
\text { come across these new banks }\end{array}$ & & 3 & 1 & 4 & 138 & 2.30 & 1.062 & 1.129 \\
\hline \begin{tabular}{|l|l|} 
12. Dahabshiil Amal effect the social 6 \\
service for the lack of strong central \\
government
\end{tabular} & & 3 & 1 & 4 & 138 & 2.30 & 1.062 & 1.129 \\
\hline $\begin{array}{l}\text { 13. Financial services that remittances } 6 \\
\text { companies cannot do without banks }\end{array}$ & & 3 & 1 & 4 & 136 & 2.27 & 1.148 & 1.318 \\
\hline Valid N (list wise) & 60 & & & & & & & \\
\hline
\end{tabular}

Descriptive statistical analysis was used to identify frequencies and percentages to answer all of the questions in the questionnaire. All respondents answered all of the questions therefore percentages reported correspond to the total number of customers answering the individual questions. The statistical significance of relationships among selected variables was determined using banks 


\subsection{Demographic Relationships and Study Variables}

Although it was not part of the purpose of the study, this set of data was intended to describe demographic variables of the sample and to assess for any influence on the research findings. The demographic data consisted of male and female. Respondents largely provided an explanation of the support or lack thereof received financial role.

\subsection{Gender Differences of the Participants in the Sample}

Participants were asked to indicate their gender by placing a tick next to the relevant Option provided (male or female).. Of the respondents 31 (51.7\%) were male and 29 (48.3\%) were female. This parts of correlations compare two questions : local companies such Dahabshiil and Amal provide you some functions of financial institution and commercial banks and Amal and Dahabshiil provide the process of payment the ways of transferring internet banking.

\begin{tabular}{|l|l|l|l|}
\hline \multicolumn{2}{|c|}{ Correlations } \\
\hline \multirow{4}{*}{ Financial Institutions } & & \multicolumn{1}{|c|}{ Financial Institutions } & \multicolumn{1}{c|}{ Commercial Banks } \\
& $\begin{array}{l}\text { Pearson } \\
\text { Correlation }\end{array}$ & 1 & $.369^{* *}$ \\
\cline { 2 - 4 } & Sig. (2-tailed) & & .004 \\
\cline { 2 - 4 } & $\mathrm{N}$ & 60 & 60 \\
\hline Commercial Banks & $\begin{array}{l}\text { Pearson } \\
\text { Correlation }\end{array}$ & $.369^{* *}$ & 1 \\
\cline { 2 - 4 } & Sig. (2-tailed) & .004 & 60 \\
\cline { 2 - 4 } & $\mathrm{N}$ & 60 & \\
\hline
\end{tabular}

**. Correlation is significant at the 0.01 level (2-tailed).

\subsection{Summary}

In this chapter, data analysis methods, study results and a discussion of the findings have been presented. Findings from this study have been found to be consistent with the findings of several related studies. In addition the impact of various demographic data on commercial bank and financial institutions has been explored.

Data findings were described as correlations to the study variables and presented as tabulations. In the implications of the findings for commercial banks and financial institutions, research will be discussed.

\section{RECOMMENDATION AND CONCLUSION}

\subsection{Conclusion and Implications}

After researcher finished of my analysis and questioner, researcher analyzed and interpreted the findings, researcher summarized my within four main parts.

- The performance of the remittance companies and its service satisfied the need of commercial banks and financial institution how can exploit getting real commercial and financial institutions which make development that people are wasting.

- People satisfy the performance of the remittances companies for the lack of banks because of strong central bank which cover the needs of the people.

- The need that people are feeling for the lack of the commercial banks and financial institutions. This was attracting any government that can make something.

- Factor that caused the growth of remittance companies. To get solution to these problems caused and to exploit fairly.

\section{RECOMMENDATION}

After researcher has paid more effort in collecting and analyzing data of my research just developed some solutions and recommendations to the groups that may concern to my topic. 
- Researcher got an idea and function missed in remittance service companies such as provide people long term loans in order to give society gain full and beneficial job.

- The remittance companies must develop system which connects s the one who served and one who has profitable business but an idea is to have fund and investment to business.

- The government must interfere and set regulations in order to gain the confidence of depositor.

- The remittance companies did not invest the large projects such as industries which are important to countries economic development; researcher suggests the remittance companies to invest these projects because the unemployment rate would decline.

\section{REFERENCES}

[1] Allen Berger, 1994. "The Relationship Between Capital and Earnings in Banking," Center for Financial Institutions Working Papers 94-17, Wharton School Center for Financial Institutions, University of Pennsylvania.

[2] Allen N. Berger \& Sally M. Davies, 1994."The information content of bank examinations," Finance and Economics Discussion Series 94-20, Board of Governors of the Federal Reserve System (U.S.).

[3] Barth, Mary E. \& Landsman, Wayne R. \&Wahlen, James M., 1995. "Fair value accounting: Effects on banks' earnings volatility, regulatory capital, and value of contractual cash flows," Journal of Banking \& Finance, Elsevier, vol. 19(3-4), pages 577-605, June.

[4] Ben Bernanke, 1990. "The Federal Funds Rate and the Channels of Monetary Transnission," NBER Working Papers 3487, National Bureau of Economic Research, Inc.

[5] Berger, Allen N, 1995. "The Relationship between Capital and Earnings in Banking," Journal of Money, Credit and Banking, Blackwell Publishing, vol. 27(2), pages 432-56, May.

[6] Douglas W. Diamond, 1984. "Financial Intermediation and Delegated Monitoring," Review of Economic Studies, Oxford University Press, vol. 51(3), pages 393-414.

[7] Gennotte, Gerard \& Pyle, David, 1991. "Capital controls and bank risk," Journal of Banking \& Finance, Elsevier, vol. 15(4-5), pages 805-824, September.

[8] Hannan, Timothy H., 1991. "Bank commercial loan markets and the role of market structure: evidence from surveys of commercial lending," Journal of Banking \& Finance, Elsevier, vol. 15(1), pages 133-149, February.

[9] James B. Thomson, 1991. "Predicting bank failures in the 1980s," Economic Review, Federal Reserve Bank of Cleveland, issue Q I, pages 9-20.

[10] Peek, Joe \&Rosengren, Eric, 1995. "Bank regulation and the credit crunch," Journal of Banking \& Finance, Elsevier, vol. 19(3-4), pages 679-692, June.

[11] Robert B. Avery \& Allen N. Berger, 1989. "Loan commitments and bank risk exposure," Finance and Economics Discussion Series 65, Board of Governors of the Federal Reserve System (U.S.).

[12] Robert C. Merton, 1995. "Financial Innovation and the Management and Regulation of Financial Institutions," NBER Working Papers 5096, National Bureau of Economic Research, Inc.

[13] Robert M. Townsend, 1979. "Optimal contracts and competitive markets with costly state verification," Staff Report 45, Federal Reserve Bank of Minneapolis.

[14] Ross, Stephen A, 1989. " Institutional Markets, Financial Marketing, and Financial Innovation," Journal of Finance, American Finance Association, vol. 44(3), pages 541-56, July.

[15] Sanford J. Grossman \& Oliver D. Hart, 1982. "Corporate Financial Structure and Managerial Incentives," NBER Chapters, in: The Economics of Information and Uncertainty, pages 107-140 National Bureau of Economic Research, Inc.

[16] Santomero, Anthony M \& Watson, Ronald D, 1977. "Determining an Optimal Capital Standard for the Banking Industry," Journal of Finance, American Finance Association, vol. 32(4), pages 1267-82, September.

[17] Timothy H \&Hanweck, Gerald A, 1988. "Bank Insolvency Risk and the Market for Large Certificates of Deposit," Journal of Money, Credit and Banking, Blackwell Publishing, vol. 20(2), pages 203-11, May.

[18] Townsend, Robert M., 1979. "Optimal contracts and competitive markets with costly state verification," Journal of Economic Theory, Elsevier, vol. 21(2), pages 265-293, October.

[19] Wall, Larry D. \& Peterson, David R., 1987. "The effect of capital adequacy guidelines on large bank holding companies," Journal of Banking \& Finance, Elsevier, vol. 11(4), pages 581-600, December. 


\section{AUTHOR's BIOGRAPHY}

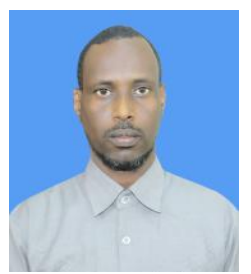

Abdifatah Dahir Harun have (MFM)-Master Financial Management at Amity University Uttar Pradesh, India and B.SC. Public Administration at Horseed International University Mogadishu, Somalia. More than 7 years experience of Government Administration as programme coordination of Galmudug State and lecturing at Horseed International University. Also I am the founder of Haldoor Institute which offers professional subjects and vocational training courses.

Citation: Mr. Abdifatah Dahir Harun. "Impact of Financial Institution on Commercial Banks (Case Study: Amal and Dahabshiil Banks in Mogadishu)". International Journal of Humanities Social Sciences and Education (IJHSSE), vol. 6, no.9, 2019, pp. 108-116. doi: http://dx. doi.org/10.20431/2349-0381.0609012.

Copyright: (C) 2019 Authors. This is an open-access article distributed under the terms of the Creative Commons Attribution License, which permits unrestricted use, distribution, and reproduction in any medium, provided the original author and source are credited. 